\title{
OPTIMALISASI TATA KELOLA BERKELANJUTAN DESTINASI WISATA PANTAI TETE: STUDI KASUS AREA PANTAI MILITER
}

\author{
Sudarmi \\ Politeknik Pariwisata Makassar \\ Email: sudarmi@poltekparmakassar.ac.id \\ Muh. Rusdi \\ Politeknik Pariwisata Makassar \\ Email: rusdipoltekparmakassar@gmail.com
}

\begin{abstract}
Sustainable Tourism Management has now become one of the main targets in environmental conservation. Including coastal tourism management through Ecotourism. The purpose of this study is to describe the evaluation of proper governance in optimizing the potential of Tete beach in Bone Regency of South Sulawesi to become a sustainable tourist destination. This study uses descriptive qualitative approach and uses observation, interviews, and documentation in collecting the data. The sampling technique used in this study was purposive sampling. The steps in analyzing the data are data processing, data analysis, and interpretation of results. The results show that the governance and the management of Tete Beach are not properly conceptualized. And so far, Tete beach management is still not optimal. These affect the local community income. Tete beach is commonly used as a military training are by TNI. Therefore it is necessary to have good planning in developing Tete beach to become a sustainable mainstay tourist destination. Eventually, good coordination is needed from the regional government, the TNI, the private sector, and the local community to increase the income of local community.
\end{abstract}

Keywords: Optimization, Sustainable Coastal Management, Tete Beach.

\section{Pendahuluan}

Dalam pembangunan ekonomi modern, sektor pariwisata memiliki sumbangsih penting terhadap pendapatan negara. Sejak beberapa dekade terakhir, banyak negara di berbagai penjuru dunia berlomba-lomba untuk meraih devisa dari sektor pariwisata. Hal tersebut sangat logis mengingat melalui sektor pariwisata negara dapat membuka lapangan pekerjaan dan juga dapat menekan angka 
kemiskinan (Pitana \& Diarta, 2009). Bahkan di wilayah perbatasan antar negara, sektor pariwisata masih menjadi angin segar untuk peningkatan ekonomi warganya, meskipun kemungkinan terburuk akan dapat memicu konflik kepentingan pengelolaan (Taena \& Afoan, 2020). Dengan kata lain, pariwisata dalam pandangan banyak negara merupakan jalan bagi peningkatan kesejahteraan masyarakat.

Secara umum pariwisata dapat dimaknai sebagai aktivitas yang dilakukan oleh seseorang pada saat tertentu dengan berbagai tujuan diantaranya untuk berlibur, memenuhi hasrat (jalan-jalan), dan sebagainya serta dilakukan di tempat lain sehingga mengharuskan seseorang melakukan perjalanan (Zalukhu \& Meyers, 2009). Dalam pandangan yang lain, pariwisata merupakan suatu kegiatan di luar rutinitas sehari-hari yang memungkinkan untuk tinggal sementara di suatu tempat dengan tujuan bersenang-senang. Definisi pariwisata memiliki ruang lingkup yang cukup luas, tidak hanya terkait pada masalah destinasi wisata saja, namun juga melakukan kegiatan yang berhubungan dengan kebutuhan seseorang (Muljadi, 2009). Individu yang melakukan aktivitias wisata, pada intinya cenderung akan bertujuan untuk berlibur, dan melupakan sejenak kesibukan bekerja (Noviantoro \& Zurohman, 2020).

Selanjutnya, isu daya saing destinasi pariwisata Indonesia cukup menantang untuk ditelaah. Namun demikian, butuh langkah-langkah strategis sekaligus aksi nyata sehingga kedepannya layak untuk dieksplorasi. Persaingan sektor pariwisata membuat pengelola destinasi objek wisata berpikir keras untuk meningkatkan pangsa pasar yang kompetitif sehingga membutuhkan langkah strategis untuk menarik wisatawan. Oleh karenanya diperlukan upaya dalam meningkatkan pelayanan dan daya saing produk pariwisata agar dapat menembus persaingan pasar wisatawan global. (Damanik, 2013). Menghadapi daya saing yang ketat, salah satu hal yang paling penting dikuasai yakni pengelolaan tempat wisata. Di masa yang akan datang, hal tersebut diprediksi dapat memacu peningkatan jumlah kunjungan wisatawan. Di lain sisi, pihak pemerintah daerah juga harus dapat bertindak sebagai pengelola 
kepariwisataan yang baik. Pemerintah harus mampu menemukan hal positif maupun negatif terkait dengan tempat wisata, sehingga dalam pengelolaan dan manajemen pariwisata dapat merata diperankan oleh seluruh unsur yang ada di sekitarnya baik dari pemerintah, pihak swasta, dan terutama masyarakat lokal, semuanya dapat berjalan sesuai dengan harapan bersama (Nuryanti, 1997).

Menurut Pitana \& Diarta (2009) bahwa di dalam manajemen pariwisata terdapat nilai-nilai yang harus dipenuhi agar keseimbangan alam tetap terjaga. Beberapa nilai tersebut juga harus dijadikan prinsip dasar dalam pengelolaan kepariwisataan yang meliputi nilai kelestarian lingkungan, komunitas, dan nilai sosial. Selain itu, tata kelola kelembagaan perlu mempertimbangkan beberapa hal, yaitu: kewenangan, karakteristik, kebutuhan, kemampuan keuangan, sumber daya organisasi, sumber daya manusia, pengembangan pola kemitraan, dan lain-lain. Melalui hal tersebut strategi dalam sebuah pengembangan pariwisata yang diharapkan dapat tercapai dengan baik (Sedarmayanti, 2014).

Koordinasi yang baik antar berbagai unsur pengelola kepariwisataan yang terdiri dari pemerintah, pihak swasta, dan masyarakat lokal merupakan kunci terlaksananya tata kelola yang baik dalam pengelolaan destinasi wisata (Sunaryo, 2013). Oleh karenanya secara normatif, pemerintah daerah harus berupaya semaksimal mungkin dalam mengembangkan potensi kepariwisataan yang ada, terutama pemenuhan sarana dan prasarana pariwisata (Primadany, 2013).

Pengelolaan tempat wisata sangat kompleks. Mulai dari tahap awal rencana persiapan yang berkaitan dengan potensi wisata yang meliputi aspek fisik dan sosial, perijinan AMDAL (Analisis Masalah Dampak Lingkungan), hingga analisis keruangan sosio-ekonomi masyarakat setempat. Namun belakangan seiring banyaknya wisata alam baru yang dibuat, seakan-akan masalah lingkungan begitu sangat dikesampingkan. Banyak kasus yang terjadi perkembangan wisata cenderung mencemari lingkungan dan bahkan merusak alam. Misalnya dengan banyaknya 
sampah berserakan akibat banyak pengunjung yang datang saat puncak musim liburan atau saat sedang viral. Meskipun di sisi lain dampak positifnya adalah pendapatan masyarakat dan pihak pengelola wisata mengalami peningkatan.

Di Indonesia, sebagian masyarakat telah sadar wisata. Akan tetapi tidak sedikit pula yang masih apatis dan kurang peduli terhadap potensi destinasi wisata di sekitar lingkungannya (Yasir et al., 2019). Banyak sekali destinasi wisata yang berupa wisata alam, budaya, edukasi dll, yang sebenarnya memiliki potensi namun kurang berkembang sehingga akhirnya tidak berdampak baik bagi lingkungan dan masyarakat sekitar. Diantara yang ada tersebut salah satunya yaitu keberadaan destinasi pantai Tete di kabupaten Bone, Sulawesi Selatan.

Pantai Tete berada di bagian selatan Kabupaten Bone, sekitar $61 \mathrm{~km}$ dari pusat Kota Watampone tepatnya di desa Bone Pute Kecamatan Tonra. Objek wisata ini tergolong baru karena keberadaannya yang masih belum familiar dibandingkan objek wisata lainnya (Ramli et al., 2019). Sebagaimana kebanyakan, pantai yang belum begitu banyak pengunjung biasanya masih sangat alami. Pantai Tete biasanya dijadikan sebagai tempat rekreasi bagi masyarakat lokal dan menjadi tempat latihan atau pusat pendidikan TNI yang baru dilantik.

Pantai Tete juga kerap dijadikan sebagai tempat simulasi perang karena wilayahnya yang strategis dan representatif mulai dari laut, udara, hingga daratannya. Pada dasarnya pantai ini juga berpeluang untuk dijadikan sebagai destinasi baru di Kabupaten Bone (Ramli et al., 2019). Ironisnya pantai tersebut hingga kini belum berkembang secara optimal menjadi destinasi wisata yang banyak dikenal oleh masyarakat luas. Salah satu penyebab utamanya adalah belum dilakukan langkah kongkrit oleh pihak pemerintah daerah dalam hal ini Dinas Pariwisata Kabupaten Bone untuk melakukan koordinasi khususnya dalam hal kerjasama dalam bentuk pengelolaan. 
Potensi keindahan yang menjadi keunikan daya tarik wisata alam Pantai Tete terdiri dari kualitas air yang jernih, pasir putih yang memukau pengunjung, serta nilai sejarah yang dapat dimanfaatkan bagi para pelajar dan peneliti sebagai bahan edukasi. Sedangkan kondisi fisik yang dapat ditemukan di Pantai Tete masih terdapat berbagai kekurangan yang perlu segera dibenahi seperti kondisi pantai yang kurang terawat, terdapat sampah berserakan di pinggir pantai, aksesbilitas yang masih rusak, sarana dan prasarana belum memadai, belum terdapatnya tempat informasi di lokasi hingga bentuk pengelolaannya yang belum jelas dan masih kurang sesuai dengan prinsip pembangunan berkelanjutan. Hal inilah yang menjadi dasar tujuan peneliti untuk memberikan gambaran evaluasi tata kelola atau pun strategi yang tepat dalam pengelolaan destinasi wisata pantai Tete agar menjadi destinasi wisata andalan yang berdaya saing, berkelanjutan, dan terutama dapat meningkatkan pendapatan bagi masyarakat sekitar.

\section{Metode Penelitian}

Penelitian dilakukan di pantai Tete Kabupaten Bone Sulawesi Selatan. Penelitian dilakukan pada bulan Mei-September 2019. Penelitian ini termasuk penelitian deskriptif dengan menggunakan pendekatan kualitatif. Dalam penelitian digunakan data primer dan sekunder. Data primer yaitu seluruh data yang didapat langsung saat wawancara dengan pihak terkait maupun dari kuesioner yang disebar di lapangan. Sedangkan data sekunder adalah seluruh data yang didapat dari berbagai sumber referensi yang relevan. Data sekunder yang didapat dari survei instansi pemerintah terdiri dari Bappeda Kabupaten Bone, Dinas Pariwisata Kabupaten Bone, dan Kecamatan Tonra. Adapun bentuk data sekunder diantaranya yaitu jurnal penelitian, laporan, artikel, peta, perundang-undangan, serta bahan studi kepustakaan lain yang berhubungan dengan topik penelitian. 
Teknik pengumpulan data yang digunakan yaitu observasi, wawancara, dan dokumentasi. Sedangkan teknik pengambilan sampel yang digunakan dalam penelitian ini adalah purposive sampling. Informan ditetapkan dengan snowball sampling. Adapun teknik analisis datanya menggunakan analisis deskriptif kualitatif dengan langkah-langkah, yaitu: pengolahan data, analisis data, dan penafsiran hasil analisis data tentang pengelolaan Pantai Tete sebagai destinasi wisata di Kabupaten Bone.

\section{Hasil dan Pembahasan}

\section{Bentuk Pengelolaan Pantai Tete}

Kabupaten Bone memiliki sejumlah destinasi wisata alam yang potensial. Berikut ini daftar jumlah dan jenis destinasi di Kabupaten Bone.

Tabel 1. Jenis Destinasi Wisata Alam di Kabupaten Bone

\begin{tabular}{|c|c|c|c|}
\hline No. & Jenis Destinasi & Lokasi & Atraksi Wisata \\
\hline 1 & Air Terjun Era & Desa Bontojai & Air terjun tingkat 7 \\
\hline 2 & Goa Uhalie & Desa Langi & Manusia purba \\
\hline 3 & Bendung Sanrego & $\begin{array}{l}\text { Desa } \\
\text { Sanrego }\end{array}$ & Tempat lomba perahu \\
\hline 4 & Toae & Desa Ancu & $\begin{array}{l}\text { Tempat berkumpulnya } \\
\text { raja-raja Bone terdahulu }\end{array}$ \\
\hline 5 & Permandian Waetuo & Desa Ulu & $\begin{array}{l}\text { Permandian dengan } \\
\text { sumber mata air }\end{array}$ \\
\hline 6 & Bendungan Salomekko & $\begin{array}{l}\text { Desa Ulu } \\
\text { Balang }\end{array}$ & Tempat memancing \\
\hline 7 & Makam Datu Salomekko & Desa Manera & Makam raja Salomekko \\
\hline 8 & Pantai Bone Lampe & $\begin{array}{l}\text { Desa Bulu- } \\
\text { Bulu }\end{array}$ & $\begin{array}{l}\text { Wisata pantai pasir } \\
\text { putih }\end{array}$ \\
\hline
\end{tabular}


Optimalisasi Tata Kelola Berkelanjutan Destinasi Wisata Pantai Tete...

\begin{tabular}{|c|c|c|c|}
\hline \multirow{2}{*}{9} & \multirow{2}{*}{ Goa Bala Batu } & Desa & Gua yang \\
\hline & & Tollonge & keindahan \\
\hline 10 & Pantai Ujung Pattiro & Desa Pattiro & Area Pemancingan Ikan \\
\hline 11 & Gua Jepang & Desa Bacu & $\begin{array}{l}\text { Tempat persembunyian } \\
\text { orang Jepang. }\end{array}$ \\
\hline 12 & Sumpang Labbu & Desa Lilina & $\begin{array}{l}\text { Terowongan } \\
\text { peninggalan }\end{array}$ \\
\hline & & & Belanda. \\
\hline
\end{tabular}

Sumber : Dinas Pariwisata Kabupaten Bone, 2019

Dari beberapa destinasi di atas, dapat dikatakan bahwa keberadaan destinasi Pantai Tete belum masuk dalam daftar pengelolaan pihak Dinas Pariwisata Kabupaten Bone. Hal tersebut dikarenakan Pantai Tete masih dalam kepemilikan pihak TNI belum diperuntukkan secara umum untuk dijadikan sebagai tempat berlibur atau berwisata. Pantai Tete memang masih dijadikan sebagai tempat pelatihan bagi tentara, namun alam Pantai Tete ini memiliki sejuta potensi yang unik dan menarik untuk dikembangkan dan sangat diminati oleh masyarakat luas khususnya warga Kabupaten Bone sendiri sebagai wisatawan lokal.

Salah seorang warga Desa Bone Puteh Kecamatan Tonra, Andi Irwan (35 tahun) menjelaskan pada peneliti (Wawancara 10 November 2019) bahwa sampai saat ini kondisi Pantai Tete masih dalam kondisi yang biasa saja dan tidak menunjukkan sebuah destinasi pada umumnya. Hal ini dikarenakan lokasi destinasi wisata tersebut pada dasarnya bukan diperuntukkan sebagai tempat untuk melakukan kegiatan rekreasi akan tetapi lokasi tersebut sepenuhnya milik TNI Kabupaten Bone yang peruntukannya hanya untuk pelatihan para prajurit. Oleh sebab itu untuk mewujudkan pengelolaan Pantai Tete secara maksimal sebagai destinasi baru yang dapat diandalkan maka diperlukan adanya bentuk kerjasama antara pihak TNI dan pihak Dinas Pariwisata. Terutama dalam hal koordinasi untuk pengembangan pengelolaan di lokasi Pantai Tete tersebut. 
Hal ini perlu segera dilakukan mengingat antusiasme masyarakat lokal bahkan dari luar daerah Kabupaten Bone memiliki keinginan kuat untuk berkunjung ke lokasi Pantai Tete. Respon dari masyarakat tersebut perlu segera dipenuhi agar menjadikan Pantai Tete sebagai destinasi baru di Kabupaten Bone Provinsi Sulawesi Selatan.

\section{Strategi Pemerintah dalam Pengembangan Pantai Tete}

Salah satu strategi yang dapat dilakukan pemerintah Kabupaten Bone dalam mengembangan destinasi wisata Pantai Tete yakni melakukan perencanaan. Hal tersebut penting dilakukan Dinas Pariwisata Kabupaten Bone karena dalam mengelola destinasi wisata alam yang dibutuhkan adalah adanya kemampuan untuk melakukan perencanaan pengembangan dengan baik yang dapat difokuskan pada produk wisata, seperti; daya tarik wisata, fasilitas wisata/umum (fasilitas di lokasi tersebut belum memenuhi syarat dan bentuknya masih sangat sederhana), dan aksesbilitas yang belum maksimal perbaikannya. Oleh karena itu, untuk mencapai pengembangan dan pengelolaan Pantai Tete yang baik, diharapkan adanya keterlibatan masyarakat lokal yang terdapat di sekitar destinasi untuk turut serta dalam setiap kegiatan pariwisata.

Adapun potensi yang dimiliki Pantai Tete sebagai destinasi wisata dapat dilihat pada tabel berikut ini:

Tabel 2. Potensi Pantai Tete Kabupaten Bone

\begin{tabular}{|c|c|c|}
\hline No. & Nama Potensi & Keterangan \\
\hline 1 & $\begin{array}{l}\text { Terdapat Barak atau tempat menginap prajurit yang } \\
\text { latihan }\end{array}$ & Kondisi baik \\
\hline 2 & Latihan para prajurit yang sangat memukau di pantai & $\begin{array}{l}\text { Dilakukan pada } \\
\text { waktu tertentu }\end{array}$ \\
\hline 3 & Memiliki nilai sejarah yang panjang & Untuk penelitian \\
\hline 4 & Memiliki keindahan laut yang memukau & Sangat jernih \\
\hline 408 & JUMPA Volume 8, Nomor 2, Januari 2022 & \\
\hline
\end{tabular}


5

6

7

8

9

10
Pasirnya yang berwarna putih mengkilat

Terdapat jalur yang membelah air laut menuju ke pulau ketika air pantai surut

Memiliki makanan khas Bone (olahan kepiting)

Memiliki fasilitas, musollah, toilet dan kamar mandi

Memiliki warung makan

Memiliki fasilitas penyewaan Ban Dalam buat berenang
Sangat unik

Terlihat pada waktu tertentu

Wisata kuliner

Masih perlu

pembenahan

Belum sesuai

standar

Masih terbatas

jumlahnya

Sumber : Data Primer, 2019

Dari data diatas dapat dikemukakan bahwa potensi Pantai Tete memang sudah cukup memadai, akan tetapi masih butuh kerja ekstra agar potensi yang ada tersebut dapat dimaksimalkan penggunaannya oleh para wisatawan. Harus dipahami bahwa wisatawan berkunjung ke suatu destinasi tertentu agar dapat merileksasi pikiran dan tubuhnya dari penatnya aktivitas sehari-hari. Namun, kekecewaan tentunya yang akan didapat oleh para wisatawan manakala destinasi tujuan yang dikunjungi tidak memiliki fasilitas sesuai ekspektasi. Maka dari itu begitu pentingnya perencanaan sebagai salah satu strategi pemerintah dalam pengembangan Pantai Tete.

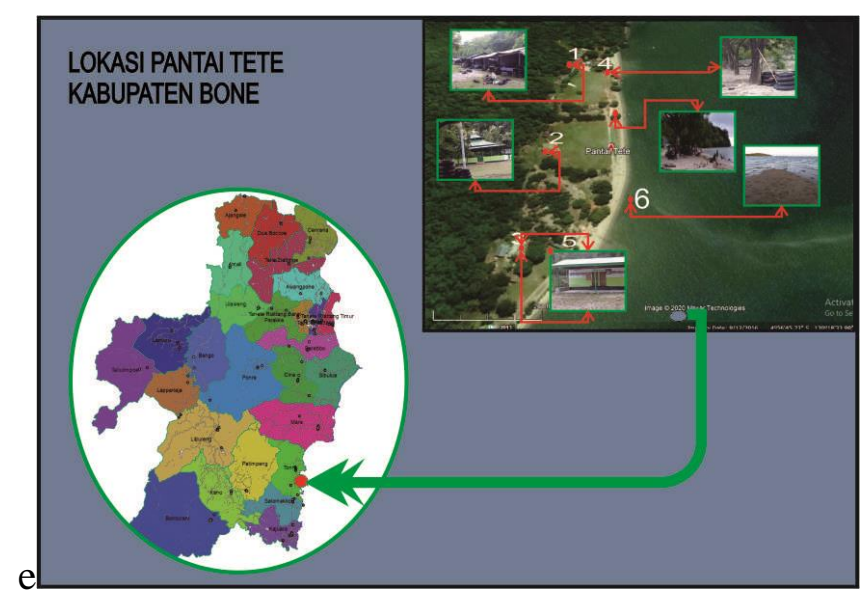

Gambar 1. Sebaran Sarana dan Prasarana Pantai Tete (Sumber: Survei lapangan, 2019) 
Pentingnya perencanaan dalam pengembangan kepariwisataan diperjelas dalam undang-undang nomor 10 tahun 2009 bahwa ketika membangun pariwisata seharusnya melakukan perencanaan terlebih dahulu baik yang berskala besar ataupun makro yang dapat diwujudkan dengan terlebih dahulu membuat rencana induk pembangunan pariwisata nasional/daerah. Perencanaan sebaiknya dilakukan pihak pemerintah dalam pengembangan destinasi wisata Pantai Tete. Diantaranya yaitu berupaya untuk melakukan berbagai proses secara sistematis dalam melaksanakan perencanaan tersebut. Adapun sistematisasi perencanaan yang dimaksud dijelaskan berikut ini.

\section{a. Proses pengajuan anggaran}

Dalam tata kelola administrasi, pengajuan rencana anggaran merupakan sesuatu yang sangat penting. Termasuk dalam penyelengaraan pemerintah. Apapun bentuk perencanaan dalam pembangunan, muaranya dipastikan akan dihadapkan pada pengajuan anggaran. Oleh karenanya rencana awal ini juga turut menentukan keberhasilan program akhir yang dicanangkan. Hal tersebut wajar dapat terjadi mengingat tujuan akhirnya adalah untuk menyejahterakan rakyat.

Pentingnya penganggaran juga dikemukakan Hansen et al., (2007), Budget are financial plans for future; they identify objectives and the actions needed to achieved them". Dalam terjemahan bebasnya, dapat dikatakan bahwa anggaran adalah bentuk rencana detail dalam menatap masa depan yang dinyatakan secara kuantitatif. Lebih dari itu, anggaran juga dapat dimaknai sebagai segala sumber daya yang dapat digunakan dan dipersiapkan untuk meraih tujuan yang dicita-citakan pada masa yang akan datang. Untuk proses pengajuan anggaran dalam upaya pengembangan Pantai Tete dapat dilakukan dengan tahapan-tahapan berikut ini:

a) Uji kelayakan terhadap keberadaan produk wisata dan daya dukung Pantai Tete dalam mendukung proses pengajuan penganggaran. 
b) Pengajuan penyusunan kerangka acuan kerja oleh pihak pengelola Pantai Tete sebagai landasan dasar untuk pengajuan anggaran.

c) Pihak pengelola Pantai Tete juga melakukan penyusunan rencana anggaran biaya.

\section{b. Persiapan pelaksanaan pengelolaan Pantai Tete}

Semenjak otonomi daerah resmi diberlakukan, pengembangan kebijakan lokal dapat diterapkan pemerintah daerah. Agar pelaksanaan kebijakan tersebut dapat berjalan maksimal, maka peningkatan kualitas sumber daya manusia dan finansial yang mumpuni merupakan kunci utamanya. Dengan demikian, tidak ada lagi yang namanya terjadi keterlambatan dalam pembangunan. Untuk itu, persiapan pelaksanaan pengelolaan Pantai Tete agar menjadi destinasi yang dapat bersaing dengan destinasi wisata lainnya yang telah ada, dapat dilakukan hal-hal berikut: (a) Membentuk Panitia Lelang; (b) Menyusun kerangka acuan kerja; (c) Menyusun jadwal lelang; (d) Evaluasi penyedia (POKJA); (e) Mengumumkan pemenang lelang; (f) Membuat kontrak pelaksanaan pekerjaan; (g) Penandatanganan kontrak pelaksanaan pekerjaan.

\section{c. Pelaksanaan perencanaan oleh pihak swasta}

Pada tahap perencanaan, secara ideal seluruh stakes holder perlu dilibatkan untuk memperoleh hasil yang optimal. Tidak terkecuali pihak swasta. Setidaknya terdapat tiga poin yang dipertimbangkan pemerintah untuk melakukan kerjasama dengan pihak swasta, yakni Public, Privat, Partnership/PPP. Hal ini perlu dilakukan mengingat limitasi dana, efisiensi dan efektivitas pemerintahan, serta bentuk tanggung jawab kepada masyarakat. Sebagai destinasi wisata yang akan dikembangkan, pemerintah daerah tidak hanya dapat mengandalkan sumber daya seadanya (Sumber Daya Manusia dan finansial). Pemerintah daerah juga membutuhkan pihak swasta untuk diajak bekerja sama dalam bentuk investasi. Investasi tidak hanya dalam bentuk dana tetapi juga peningkatan skill SDM untuk 
membangun dan memelihara infrastruktur yang belum dan sudah tersedia dalam rangka menyejahterakan masyarakat. Dengan kata lain, proses perencanaan pihak swasta (pemenang tender) yang dipercayakan oleh pihak pemerintah sebagai pelaksana pekerjaan harus mampu melaksanakan pekerjaan tersebut dengan sebaikbaiknya agar manfaat maksimal dapat dirasakan masyarakat.

\section{d. Pembentukan tim kerja pengelolaan Pantai Tete}

Keberadaan pihak swasta dalam pengembangan destinasi wisata Pantai Tete merupakan bagian dari pemerintah sebagai motor penggerak pembangunan. Melalui jargon Public, Privat, Partnership (PPP) diharapkan akan tercipta suasana dan sistem pemerintahan yang bersih. Hal tersebut dapat terjadi karena masing-masing antar pihak swasta dan pemerintah dapat menjadi fungsi kontrol yang baik. Akan tetapi perlu ditekankan bahwa relasi yang terjalin antara pemerintah dan pihak swasta harus berdasarkan interaksi saling menguntungkan dan terikat pada kontrak perjanjian tertentu. Pada titik ini peran dan fungsi pemerintah untuk mengontrol pelaksanaan pembangunan diperlukan. Oleh karenanya diperlukan pengawasan dari pemerintah dengan adanya pembatasan waktu. Adapun pembentukan tim kerja pengelolaan Pantai Tete dapat dilakukan dengan hal-hal berikut: (1) Pembentukan tim ahli (sesuai dengan kerangka acuan kerja lelang); (2) Pembentukan tim surveyor (tenaga lapangan); (3) Mempersiapkan fasilitas yang dibutuhkan (mulai tahap perencanaan).

\section{e. Perumusan tujuan dan sasaran}

Terdapat beberapa hal yang menjadi tujuan dan sasaran dari pengembangan pengelolaan destinasi wisata Kabupaten Bone, yaitu:

a) Peningkatan kemakmuran secara ekonomi

b) Pengembangan industri pariwisata

c) Peningkatan kualitas serta akses layanan pendidikan 
d) Mengembangkan keragaman budaya

e) Merevitalisasi nilai kebudayaan maritim

Dari lima tujuan pengembangan pengelolaan destinasi wisata di atas, sasaran yang hendak dicapai yakni meningkatkan kenyamanan bersama, mengembangkan kualitas dan keragaman destinasi wisata, aksesbilitas wisatawan(pengunjung), kelestarian alam, serta yang paling utama adalah meningkatkan kesejahteraan masyarakat lokal. Selain itu, sasaran yang lainnya yakni meningkatnya kemitraan dan usaha ekonomi kreatif bidang pariwisata. Artinya, tingkat keberhasilan kerjasama yang dijalin oleh pemerintah melaui berbagai pihak baik dengan pelaku usaha atau pun masyarakat lokal sekitar destinasi wisata bergantung pada perkembangan daya saing industri pariwisata tersebut.

Berdasarkan beberapa hal yang telah diuraikan di atas, maka strategi pemerintah dalam pengembangan Pantai Tete sebagai destinasi wisata, yaitu:

a) Pengelolaan Pantai Tete harus berdasarkan hasil kesepakatan mufakat dari seluruh stakeholders yang berperan

b) Memberikan manfaat dan penghidupan kepada masyarakat, baik yang bersifat materiil maupun yang non materiil (kultural, spiritual, dan intelektual)

c) Tata kelola pantai Tete harus mengimplementasikan prinsip pembangunan berkelanjutan yakni berorientasi pada keseimbangan ekologis dan tatanan sosial sehingga sejalan dengan nilai sosial-budaya masyarakat lokal.

d) Hendaknya dalam pengelolaan destinasi Pantai Tete sebaiknya dapat dikendalikan dengan baik agar dapat menjaga kelestarian lingkungan sehingga tidak melampaui ambang batas daya dukung yang ada. 


\section{Peran serta Masyarakat dalam mendukung destinasi pariwisata berkelanjutan di Pantai Tete}

Pada prinsipnya pengembangan pariwisata tidak semata-mata berorientasi pada aspek ekonomi. Salah satu faktor pendukung suksesnya pembangunan industri pariwisata di kawasan wisata alam Pantai Tete yaitu dengan menerapkan "Sapta Pesona Pariwisata Indonesia" atau dikenal dengan istilah 7-K, yang terdiri dari keamanan, Ketertiban, Kebersihan, Kesejukan, Keindahan, Keramahan, dan Kenangan. Selanjutnya, aspek lain yang mendasar dan tidak kalah penting melalui pengembangan pariwisata yakni dapat terciptanya kondusifitas iklim industri terhadap keadaan sekitarnya. Iklim kondusif tersebut dapat berupa dukungan, penerimaan, dan partisipasi masyarakat terhadap pengembangan destinasi wisata. Untuk konteks pembahasan dukungan dan peran serta masyarakat dalam aktivitas pariwisata yang ada pada suatu destinasi, maka konsep "Sadar Wisata" harus terinternalisasi dalam diri setiap masyarakat. Karena dalam konsep tersebut terdapat dua misi atau sasaran utama yaitu:

a) Mendorong masyarakat di kawasan Pantai Tete agar menciptakan iklim yang baik dalam pengembangan kepariwisataan, setidaknya menjadi tuan rumah yang "welcome".

b) Mendorong masyarakat untuk berpartisipasi menjadi pelaku aktif di sekitar kawasan pantai Tete. Misalnya dengan berjualan, menyediakan fasilitas penginapan, atau hanya sekedar menjadi wisatawan lokal/ pengunjung harian.

Peran serta masyarakat dalam pengelolaan Pantai Tete sebagai destinasi wisata di Kabupaten Bone pada dasarnya adalah untuk kepentingan masyarakat itu sendiri. Artinya, dengan mereka ikut andil dalam pengelolaan bersama pemerintah dan pihak swasta, maka paling tidak akan berdampak pada perbaikan ekonomi mereka. Hal tersebut sesuai dengan pandangan (Sunaryo, 2013) bahwa keberhasilan pengembangan pariwisata bergantung pada keterlibatan aktif masyarakat ataupun 
komunitas lokal dalam menjembatani ketersediaan fasilitas destinasi wisata, sehingga pada akhirnya akan berdampak pada perekonomian masyarakat sekitar. Dalam pengembangan kepariwisataan, peran masyarakat tidak kalah penting dengan pemangku kebijakan yang lain seperti pemerintah dan pihak swasta. Lebih lanjut, mengatasi rendahnya partisipasi masyarakat terhadap pariwisata dapat ditempuh melalui pendampingan dan advokasi. Oleh karena itu Musadad (2018) mengemukakan bahwa dibutuhkan program advokasi atau pendampingan dari para pemangku kepentingan yang ada untuk meminimalisasi masalah-masalah tersebut. Adapun bentuk peran serta masyarakat dalam pengembangan destinasi wisata Pantai Tete yaitu keterlibatan dalam mengikuti rapat, saling bertukar pendapat, berbagi pengalaman, dan bertukar informasi mengenai strategi, pengelolaan, dan pengembangan destinasi.

Lebih dari itu, kesadaran masyarakat dalam mengembangan potensi wisata pantai Tete harus juga didasari dengan kesadaran pentingnya pembangunan berkelanjutan. Pengembangan pantai Tete setidaknya harus mengarah pada kelestarian lingkungan, berorientasi pada keberlangsungan kehidupan masa yang akan datang, serta berdampak posistif bagi kehidupan sekitar. Dengan demikian keberadaan pantai Tete sebagai objek wisata akan sinergi berdampak positif baik secara fisik maupun sosial.

\section{Pengelolaan Ekowisata Berkelanjutan di Pantai Tete}

Dalam membangun objek wisata yang berkelanjutan diperlukan sistem pengelolaan secara terpadu dan terintegrasi yang berasal dari berbagai unsur yang ada. Sistem tersebut antara lain melibatkan semua stakeholders yang berperan mulai dari tahap perencanaan, pelaksanaan, hingga pemantauan dan evaluasi. Stakeholders dapat berasal dari pemerintah Kabupaten Bone, masyarakat lokal sekitar Pantai Tete, pelaku bisnis, peneliti, akademisi, wisatawan maupun LSM (Sutiarso, 2018). 
Sistem pengelolaan yang terpadu akan memaksa untuk berbagi peran pada masing-masing stakeholders. Pemerintah bertugas membuat kebijakan dan aturan terkait perencanaan, pembagian zonasi, serta eksekusi pembangunan lokasi ekowisata. Pemerintah juga berkewajiban memperbaiki pembangunan infrastruktur sekitar area objek wisata Pantai Tete disamping juga mempersiapkan sarana air yang bersih, sanitasi lingkungan, serta sistem pembuangan akhir. Sementara stakeholder lain juga memiliki peran dalam bentuk tanggung jawab untuk menekan dampak negatif yang akan muncul seperti dampak terhadap lingkungan, sosial budaya, serta perekonomian masyarakat.

Secara ekologis perencanaan dengan pengukuran daya dukung lingkungan sangat penting dilakukan sebelum lokasi Pantai Tete dikembangkan menjadi kawasan ekowisata. Hasil dari pengukuran tersebut kemudian dapat dijadikan acuan terkait daya dukung alam untuk menyokong kegiatan ekowisata. Seperti penataan ruang, ketersediaan air bersih, dan keberagaman flora-fauna yang terdapat di sekitar pantai Tete. Daya dukung lingkungan tersebut akan berkaitan erat dengan kapasitas jumlah pengunjung dalam satu waktu. Termasuk fasilitas ekowisata yang dapat dibangun dan masalah sampah yang ditimbulkan oleh aktivitas wisatawan.

Di sisi lain perencanaan pantai Tete menjadi ekowisata berkelanjutan juga harus dilakukan perhitungan biaya manfaat dari pengembangannya secara ekonomis. Dalam perhitungan biaya dan manfaat (Cost Benefit Analysis), terdapat beberapa perpektif keuntungan yang akan diperoleh. Diantaranya yaitu keuntungan ekonomis dan keuntungan sosial. Secara matematis keuntungan ekonomis menyisakan biaya yang harus ditanggung yakni biaya konservasi lingkungan. Sedangkan untuk keuntungan sosial, dengan dikembangkannya ekowisata maka kondisi sosial budaya masyarakat lokal juga dapat berkembang maksimal.

Selanjutnya untuk menunjang keberhasilan pantai Tete menjadi destinasi ekowisata berkelanjutan maka perlu dilakukan analisis pada beberapa faktor 
diantaranya faktor struktural, internal, dan eksternal. Faktor struktural yang berkaitan dengan regulasi atau kebijakan pemerintah terkait manajemen kawasan ekowisata. Adapun faktor internal mencakup peluang dan potensi daerah, partisipasi aktif masyarakat lokal, serta pemahaman pengelola terhadap sustainable development. Sedangkan faktor eksternal merupakan faktor yang berasal dari luar, misalnya berupa kesadaran pengunjung atau wisatawan terhadap kebersihan dan aktivitas riset/penelitian di wilayah ekowisata.

Selain itu, faktor penting lainnya dalam pengelolaan wisata yakni upaya pemberdayaan masyarakat (Sutiarso, 2018). Hal tersebut sangat penting karena masyarakat setempat pasti akan banyak terlibat dalam aktivitas ekowisata dan akan berdampak pada peningkatan pendapatan mereka dengan tanpa mengabaikan nilainilai kearifan lokal yang ada. Pemberdayaan masyarakat lebih diarahkan dengan harapan agar mereka mampu membuat keputusan sendiri dan melakukan inisiatif untuk pengembangan ekowisata. Salah satu program kegiatan yang sangat penting untuk meningkatkan kualitas SDM adalah capacity building. Upaya-upayanya diantaranya yaitu sosialisasi konsep ekowisata, workshop, atau pun pelatihan UMKM serta kursus untuk menjadi guide wisata. Usaha pemberdayaan juga dapat berupa pemberian bantuan dana kredit bagi warga sekitar destinasi. Dengan harapan bantuan dana tersebut dapat digunakan untuk memulai usaha-usaha yang keberadaannya mendukung keberlangsungan destinasi wisata, seperti membuka warung, penyediaan cindera mata, penginapan, tempat persewaan alat-alat berenang dan lain-lain.

Kegiatan Ekowisata sejatinya juga berdampak pada konservasi alam. Oleh karena itu penting disampaikan saat sosialisasi pemberdayaan masyarakat, agar saat berpartisipasi aktif mengembangkan destinasi wisata, mereka memiliki modal pemahaman tentang rambu-rambu konservasi. Untuk mencapai hasil maksimal, pelaksanaan ekowisata berkelanjutan juga memerlukan pengawasan dan evaluasi. Keduanya dapat dilakukan dengan dua cara, yakni secara internal dilakukan oleh 
pihak pengelola, dan secara eksternal dilakukan oleh pihak luar seperti LSM, tim independen, dan sebagainya (Wood, 2002).

\section{Kesimpulan dan Saran}

\section{Kesimpulan}

Sebagai bagian dari pengembangan wisata berkelanjutan, destinasi pantai Tete memiliki potensi yang sangat besar untuk dapat dijadikan sebagai salah satu andalan baru dalam menciptakan keanekaragaman destinasi wisata alam yang terdapat di Kabupaten Bone. Pantai ini masih alami, belum banyak terjamah oleh manusia. Untuk mencapai hasil maksimal dalam pengelolaan destinasi wisata Pantai Tete yakni melalui ekowisata berkelanjutan, maka dibutuhkan berbagai strategi yang harus dipersiapkan oleh pihak pemerintah daerah. Khususnya dalam meningkatkan hubungan kerjasama pengelolaan dari pihak TNI ke Pihak Dinas Pariwisata Kabupaten Bone. Adapun strategi yang harus dipersiapkan yaitu pembuatan Rencana Induk Pengembangan Pariwisata Daerah (RIPDA) sesuai kaedah pembangunan berkelanjutan. Hal tersebut penting dilakukan agar destinasi pariwisata yang ada di Kabupaten Bone dapat dianggarkan dan dilaksanakan pembangunan secara bertahap termasuk keberadaan Pantai Tete. Selanjutnya perlu dipersiapkan pengelola Sumber Daya Manusia yang tepat di bidang pariwisata, mengembangkan sarana dan prasarana termasuk fasilitas pendukung di lokasi destinasi. Di samping itu diperlukan juga adanya bentuk pengawasan terpadu antara pihak TNI, Dinas Pariwisata, pihak swasta, LSM Lingkungan, dan masyarakat yang terkait dengan pengelolaan destinasi Pantai Tete. 
Saran

Berdasarkan temuan penelitian, berikut beberapa rekomendasi untuk mengoptimalkan pengembangan destinasi wisata Pantai Tete:

1. Bentuk pengelolaan destinasi wisata Pantai Tete menjadi ekowisata berkelanjutan serupa dengan pengelolaan destinasi wisata bahari, namun karena memiliki karakter tersendiri, tata kelola sebaiknya melibatkan semua elemen yang ada di sekitarnya termasuk pemerintah, pihak swasta dan warga sekitar pantai Tete. Selain itu sistem pengelolaannya harus tetap sinergi dengan kearifan lokal yang ada serta sesuai dengan kaedah pembangunan berkelanjutan.

2. Karena pantai Tete sering digunakan oleh TNI, maka dibutuhkan koordinasi yang baik antara TNI dengan pihak pengelola.

3. Dalam pengembangan wisata alam Pantai Tete, maka pemerintah sebelum melakukan pembangunan dapat mempertimbangkan sembilan aspek pembangunan pariwisata, yaitu: (1) pengembangan fasilitas khusus, (2) pengembangan fasilitas umum, (3) pengembangan aksesbilitas-infrastruktur menuju destinasi, (4) pengembangan daya tarik wisata(DTW) atau keunikan destinasi, (5) pengembangan investasi, (6) pengembangan industri pariwisata, (7) pemberdayaan dan pendampingan masyarakat, (8) pencitraan dan promosi pariwisata, dan (9) harmonisasi kebijakan dan regulasi yang menjadi dasar dikembangkannya destinasi wisata.

\section{Ucapan Terima Kasih}

Dalam kesempatan ini penulis sampaikan terima kasih kepada pihak pengelola pantai Tete, Dinas Pariwisata Kabupaten Bone, Tim LP2M Poltekpar Makassar, serta pihak-pihak lain yang telah banyak berkontribusi hingga terselesaikannya riset ini. 


\section{Daftar Pustaka}

Damanik, J. (2013). Pariwisata Indonesia: Antara peluang dan tantangan. Pustaka Pelajar.

Gunn, C. A. (1994). with Var, T.(2002) Tourism Planning: Basics, Concepts, Cases. New York: Routledge.

Hansen, D., Mowen, M., \& Guan, L. (2007). Cost management: Accounting and control: Cengage Learning.

Hidayat, M. (2011). Strategi perencanaan dan pengembangan objek wisata (studi kasus Pantai Pangandaran Kabupaten Ciamis Jawa Barat). THE Journal: Tourism and Hospitality Essentials Journal, 1(1), 33-44.

Inskeep, E. (1998). Guide for local authorities on developing sustainable tourism (Vol. 1). World Tourism Organization Publications.

J Muljadi, A. (2009). Kepariwisataan dan perjalanan. Rajawali Press.

McIntyre, G. (1993). Sustainable tourism development: Guide for local planners. World Tourism Organization (WTO).

Musadad, M. (2018). Community Participation in Nature Tourism Development: Lessons From Pindul Cave in Yogyakarta, Indonesia. Jurnal Kawistara, 8(2), 169-183.

Noviantoro, K. M., \& Zurohman, A. (2020). Prospek Pariwisata Syariah (Halal Tourism): Sebuah Tantangan di Era Revolusi Industri 4.0. Equilibrium: Jurnal Ekonomi Syariah, 8(2), 275-296.

Nuryanti, W. (1997). Tourism and heritage management. Gadjah Mada University Press.

Pitana, I. G., \& Diarta, I. K. S. (2009). Introduction to tourism. Jogjakarta: Andi Offset.

Primadany, S. R. (2013). Analisis Strategi Pengembangan Pariwisata Daerah (Studi pada Dinas Kebudayaan dan Pariwisata Daerah Kabupaten Nganjuk). Jurnal Administrasi Publik, 1(4), 135-143.

Ramli, I. R., Bahar, A., \& Samad, W. (2019). Beach Tourism Development Strategy in Coastal Area District Tete Bone, South Sulawesi, Indonesia. International Journal of Environment, Agriculture and Biotechnology, 5(6).

Sedarmayanti, H. J. (2014). Manajemen Sumber Daya Manusia, Reformasi Birokrasi, Dan Manajemen Negeri Sipil. Refika Aditama.

Sunaryo, B. (2013). Kebijakan pembangunan destinasi pariwisata: Konsep dan aplikasinya di Indonesia. Penerbit Gava Media.

Sutiarso, M. A. (2018). Pengembangan Pariwisata Yang Berkelanjutan Melalui Ekowisata. 
Taena, W., \& Afoan, F. (2020). Cross Border Tourism and Regional Development: Case Indonesia-Timor Leste Cross Border. Ekuilibrium: Jurnal Ilmiah Bidang Ilmu Ekonomi, 15(1), 1-13.

Wood, M. (2002). Ecotourism: Principles, practices and policies for sustainability. UNEP.

Yasir, Y., Nurjanah, N., Salam, N. E., \& Yohana, N. (2019). Kebijakan komunikasi dalam membangun destinasi dan masyarakat sadar wisata di kabupaten bengkalis. Jurnal Studi Komunikasi, 3(3), 424-443.

Zalukhu, S., \& Meyers, K. (2009). Panduan Dasar Pelaksanaan Ekowisata. Unesco Office.

\section{Profil Penulis}

Sudarmi, SE, MM. Alumni S1 STIMI Makassar dan S2 Universitas Muhammadiyah Makassar. Saat ini aktif sebagai staf pengajar (dosen tetap) di Prodi Managemen Divisi Kamar, Politeknik Negeri Pariwisata Makassar. NIP : 197104011993032001, Golongan III/d, Jabatan Pembina.

Muh. Rusdi, S.Sos., M. Hum. Alumni S1 STIA YAPPI MAKASSAR dan S2 Universitas Padjadjaran Bandung. Saat ini aktif sebagai tenaga pengajar di Prodi Managemen Konvensi dan Perhelatan, Politeknik Negeri Pariwisata Makassar, dengan Jabatan Lektor, Golongan III/c. 